九州大学学術情報リポジトリ

Kyushu University Institutional Repository

\title{
Iron Redox Transformation by the Thermo- Acidophilic Archaea from the Genus Sulfolobus
}

\section{Masaki, Yuse i}

Department of Earth Resources Engineering, Faculty of Engineering, Kyushu University

Tsutsumi, Katsutoshi

Department of Earth Resources Engineering, Faculty of Engineering, Kyushu University

Okibe, Naoko

Department of Earth Resources Engineering, Faculty of Engineering, Kyushu University

http://hdl. handle. net/2324/4737397

出版情報 : Geomicrobiology Journal. 35 (9)，pp.757-767，2018-06-23. Taylor and Francis バージョン：

権利関係 : 
1 Geomicrobiology Journal

2 Title:

3 Iron redox transformation by the thermo-acidophilic archaea from the genus

$4 \quad$ Sulfolobus

5 (Running title: Iron redox transformation by the genus Sulfolobus)

6

7 Yusei MASAKI, Katsutoshi TSUTSUMI, Naoko OKIBE*

8

9 Department of Earth Resources Engineering, Faculty of Engineering, Kyushu University,

10744 Motooka, Nishi-ku, Fukuoka 819-0395, Japan

11

$12{ }^{*}$ Corresponding author.

13 Tel. and Fax: + 81928023312

14 E-mail address: okibe@mine.kyushu-u.ac.jp (Naoko Okibe)

15

16 Keywords: Iron redox transformation, Chromium reduction, Sulfolobus, Acidophilic

17 archaea 


\section{Abstract}

19 Iron redox transformations by five representative Sulfolobus strains (S. metallicus Kra23;

20 S. tokodaii 7; S. acidocaldarius 98-3; S. solfataricus P1; S. shibatae B12) were studied to

21 clarify the general trend of Fe metabolism across different species of the genus Sulfolobus.

22 Negligible to major Fe(II) oxidation was detected in cell-suspensions of the strains.

23 Fe(III)-reducing ability was differently expressed in each strain with dependence on the

24 oxygen level and growth status: Growth-uncoupled cell-suspensions of all strains reduced

$25 \mathrm{Fe}(\mathrm{III})$ under either anaerobic or micro-aerobic conditions, or under both conditions. A

26 linear correlation between cell growth and Fe(III) reduction was also found in S. tokodaii

27 7, S. solfataricus $\mathrm{P} 1$ and $S$. shibatae B12. In addition to Fe redox behaviors, the strains

28 were also tested for reduction of highly-toxic $\mathrm{Cr}(\mathrm{VI})$ to less toxic and soluble $\mathrm{Cr}(\mathrm{III})$, as

29 an application possibility: The trend in degree of $\mathrm{Cr}(\mathrm{V})$ reduction did not necessarily

30 correspond to that of $\mathrm{Fe}(\mathrm{III})$ reduction, suggesting the involvement of different reduction

31 mechanisms. 


\section{Introduction}

The genus Sulfolobus is generally recognized as a group of aerobic, thermoacidophilic sulfur-oxidizing archaea. They naturally occur in a number of sulfur-rich acidic geothermal environments (Brock et al. 1972; Huber and Stetter 1991; Jan et al. 1999; Zillig et al. 1993). Consequently, utilization of $\mathrm{S}^{0}$ (either autotrophically or

2002; S. metallicus, Huber and Stetter 1991; S. yangmingensis, Jan et al. 1999; S. shibatae, Grogan et al. 1990; S. tengchongensis, Xiang et al. 2003), although with an exception of non-sulfur oxidizing Sulfolobus sp. GA1, as was recently reported (Masaki et al. 2016).

Given that microbial Fe(II) oxidation plays a major role in the geochemical Fe cycle of highly acidic environments, and that a number of Sulfolobus species are widely distributed in such environments, there are yet only limited studies evaluating $\mathrm{Fe}(\mathrm{II})$ oxidation ability in this genus (S. metallicus, S. tokodaii; Bathe and Norris 2007). Owing to its both $\mathrm{Fe}(\mathrm{II})$ - and $\mathrm{S}^{0}$-oxidizing metabolisms, $S$. metallicus has been employed to apply for high-temperature bioleaching (oxidative dissolution) of sulfide minerals such as pyrite and chalcopyrite (Sandström et al. 2005; Gautier et al. 2008; Vilcáez et al. 2008; Zhu et al. 2011). A comprehensive search for Fe(II)-oxidizing ability among different Sulfolobus species would therefore lead to better understandings of the role of this genus in natural 
50 Fe cycles, as well as in possible utilities of the genus for application purposes.

52 Fe(II)-oxidizing ability: S. acidocaldarius was reported to reduce soluble $\mathrm{Fe}$ (III) to $\mathrm{Fe}(\mathrm{II})$

under aerobic conditions in the presence of elemental sulfur or glutamate as electron

54 donor (Brock and Gustafson 1976), although it was controversially pointed out that this archaeon does not grow autotrophically (Johnson et al. 2012). Our previous study detected the Fe(III)-reducing ability during growth under micro-aerobic conditions in recently isolated Sulfolobus sp. GA1 (Masaki et al. 2016). This observation thus further motivated us to investigate general trend of $\mathrm{Fe}(\mathrm{III})$-reducing ability across different representative species of the genus Sulfolobus. The possible importance of sulfur- and iron-oxidizing acidophiles in the natural geochemical Fe cycle by means of not only Fe(II) oxidation but also Fe(III) reduction was first pointed out by Brock and Gustafson (1976), by showing Fe(III)-reducing ability in Acidithiobacillus thiooxians, At. ferrooxidans and S. acidocaldarius. Later studies in fact revealed a variety of acidophiles involved in microbial Fe(III) reduction: Anaerobic growth via $\mathrm{Fe}(\mathrm{III})$ respiration using $\mathrm{S}^{0}$ (or other reduced inorganic sulfur compounds) as electron donor was reported for At. ferrooxidans (Ohmura et al. 2002), At. ferrivorans

67 (Hallberg et al. 2010), and Acidiferrobacter thiooxydans (Hallberg et al. 2011b). The 
68 ability to use Fe(III) as sole electron acceptor during heterotrophic growth was reported

69 in Sulfobacillus (Sb.) acidophilus, Sb. thermosulfidooxidans, Acidimicrobium

70 ferrooxidans (Bridge and Johnson 1998) and Acidicaldus organivorus (Johnson et al.

71 2006). Reductive dissolution of Fe(III) minerals was observed in micro-aerobic cultures

72 of heterotrophs, Acidiphilium spp. (Johnson and Mcginness 1991; Johnson and Bridge

2002; Coupland and Johnson 2008), Acidocella spp. and Acidobacterium spp. (Coupland and Johnson 2008). Based on the above biodiversity found so far, it would be reasonable to expect that Fe(III)-reducing abilities could also exist across different Sulfolobus spp. coupled with growth on $\mathrm{S}^{0}$ and/or organic substrates. In the viewpoint of biochemical Fe(II) oxidation mechanism, the responsible molecular complexes often seem quite versatile in different acidophiles: In the wellstudied mesophilic Fe-oxidizing bacterium, At. ferrooxidans, electrons transfer from $\mathrm{Fe}(\mathrm{II})$ via cytochromes $c$ and rusticyanin (Rus; a periplasmic blue copper protein), followed by the "downhill" and "uphill" pathways using a cytochrome $c$ oxidase (Cox complex) and $b c 1$ complex (PetI), respectively. Unlike At. ferrooxidans, cytochrome $c$ has not been detected in mesophilic Fe-oxidizing archaea Ferroplasma spp., but the terminal oxidase combines cytochrome $c$ oxidase-like and $b c$ complex-like components.

85 Also, a blue copper protein, sulfocyanin, may be serving as the branch point like 
rusticyanin between downhill and uphill electron flows (Bonnefoy and Holmes, 2012). In the case of iron-oxidizing thermophilic archaea, such as Sulfolobus spp. (She et al., 2001; Kawarabayashi et al., 2001; Hiller et al., 2003; Chen et al., 2005; Bathe and Norris, 2007), Metallosphaera sedula (Auernik et al., 2008) and Acidanus cophhuensis (Urbieta et al., 2017), again their genomic sequences have no evidence for cytorhrome $c$, but the fox gene cluster (encoding FoxA/FoxB with identity to cytochrome $c$ oxidase subunits, FoxC/FoxD with identity to cytochrome b558/566 subunits (CbsA-like) and others) was found, which may have an analogous role to the rus operon of At. ferrooxidans (Johnson et al., 2012). Likewise to Ferroplasma sp., sulfocyanin genes (soxE) were found in genomes of these thermophiles (cf. in the case of A. cophhuensis, an additional rusticyanin-like gene was also detected; Urbieta et al., 2017). Whilst Fe(III) reduction widely takes place among acidophilic prokaryotes, its biochemical mechanism is yet largely unknown, compared to the Fe(II) oxidation mechanism. So far most of the work focused on neutrophilic and mesophilic bacteria such as Geobacter sp. and Shewanella sp., and found that cytochromes $c$ were responsible for their Fe(III) respiration (Lovely et al., 2011; Fredrickson et al., 2008). Compared to the neutrophilic counterparts, even fewer studies are available with acidophiles. In At.

103 ferrooxidans, it was suggested that electrons travel from $\mathrm{S}^{0}$ to $\mathrm{Fe}(\mathrm{III})$ via a respiratory 
104 chain containing $b c 1$ complex and cytochrome $c$ (Osorio et al., 2013). In thermoacidophilic archaea, the involvement of cytochrome $c$ proteins seems to vary: Whilst a number of other species have few to no cytochrome $c$ genes, Ferroglobus placidus and Geoglobus ahangari contained numerous cytochromes $c$. The importance of several genes was suggested in $\mathrm{Fe}(\mathrm{III})$ respiration by $F$. placidus (i.e. three multiheme cytochromes $c$, a menaquinol oxidoreductase $\mathrm{Cbc} 4$ complex, and a unique periplasmic cytochrome $c$ fused to a cytochrome $b$-type heme/steroid binding domain (CbcZ); Smith et al., 2015).

From the viewpoint of biohydrometallurgical application, search for microbial Fe(III)-reducing abilities would benefit the development of bio-processes such as bioremediation of toxic metals (e.g., hexavalent chromium; Masaki et al. 2015; Cummings et al. 2007) and reductive bioleaching of Fe(III)-minerals (e.g., nickel laterites where $\mathrm{Ni}$ is associated with goethite; Hallberg et al. 2011a; Johnson 2012; Johnson et al. 2013; Nancucheo et al. 2014).

With the aim to clarify the roles of Sulfolobus spp. in natural geochemical Fe cycles, as well as to further explore their potentials in biohydrometallurgical applications, this study has chosen representative strains; S. metallicus Kra23, S. tokodaii 7, S. acidocaldarius $98-3$, S. solfataricus $\mathrm{P} 1$ and $S$. shibatae B12, to test and compare their Fe 
122 redox transformation capabilities as well as to search for a genetic clue to support their

123 Fe transformation behaviors by analyzing the available genome sequences. Additionally,

124 their abilities in $\mathrm{Cr}(\mathrm{VI})$ reduction were also investigated to compare with those in $\mathrm{Fe}$ (III)

125 reduction. 


\section{Microorganisms}

S. metallicus Kra23 ${ }^{\mathrm{T}}$ (DSM 6482), S. tokodaii $7^{\mathrm{T}}$ (DSM 16993), S.

acidocaldarius $98-3^{\mathrm{T}}$ (DSM 639), S. solfataricus $\mathrm{P} 1^{\mathrm{T}}$ (DSM 1616) and S. shibatae $\mathrm{B} 12^{\mathrm{T}}$

(DSM 5389) were purchased from the National Institute of Technology and Evaluation

(Tokyo, Japan).

S. tokodaii 7 and S. shibatae B12 were maintained and pre-grown in $300 \mathrm{~mL}$

Erlenmeyer flasks containing $150 \mathrm{~mL}$ of heterotrophic basal salts (HBS) medium (pH

$(\mathrm{w} / \mathrm{v})$ yeast extract. Elemental sulfur $\left(\mathrm{S}^{0} ; 0.1 \%(\mathrm{w} / \mathrm{v})\right)$, instead of glucose, was added to HBS medium ( $\mathrm{pH} 2.5$ with $\mathrm{H}_{2} \mathrm{SO}_{4}$ ) for $S$. metallicus $\mathrm{Kra} 23, S$. acidocaldarius $98-3$ and duplicates. 

at the late exponential phase by centrifugation $(12,000 \mathrm{~g}, 10 \mathrm{~min})$, washed twice, and containing $10 \mathrm{mM} \mathrm{Fe}(\mathrm{II})\left(\right.$ as $\mathrm{FeSO}_{4} \cdot 7 \mathrm{H}_{2} \mathrm{O}$ ): Densities of the resultant cell-suspensions were approx. $5 \times 10^{8}$ cells $\mathrm{mL}^{-1}$ for $S$. tokodaii 7 and $S$. shibatae B12, and $2 \times 10^{8}$ cells $\mathrm{mL}^{-}$

${ }^{1}$ for S. metallicus Kra23, S. acidocaldarius 98-3 and S. solfataricus P1. Cell-suspensions were incubated shaken $\left(70^{\circ} \mathrm{C}, 120 \mathrm{rpm}\right)$ and samples were regularly taken to monitor the concentrations of Fe(II) and total soluble Fe. between Sulfolobus strains) were calculated. density of $1 \times 10^{9}$ cells $\mathrm{mL}^{-1}$ ) in $10 \mathrm{~mL}$ of HBS medium (in $25 \mathrm{~mL}$ serum bottles with 
rubber stoppers; $\mathrm{pH} 2.0)$ containing $10 \mathrm{mM} \mathrm{Fe}(\mathrm{III})\left(\mathrm{as} \mathrm{Fe}_{2}\left(\mathrm{SO}_{4}\right)_{3} \cdot \mathrm{nH}_{2} \mathrm{O}\right)$. One millimolar glucose ( $\mathrm{N}_{2}$-purged) and $0.01 \% \mathrm{~S}^{0}$ were tested as electron donor (except for the case of $S$. metallicus Kra23, where only $\mathrm{S}^{0}$ was used). All solutions used for anaerobic experiments were $\mathrm{N}_{2}$-purged until the DO (dissolved oxygen) level reached $<0.1 \mathrm{mg} \mathrm{L}^{-1}$ (DO-14P; TOA-DKK). After that, all media preparations were conducted in the anaerobic chamber and incubated (unshaken, $70^{\circ} \mathrm{C}$ ).

Micro-aerobic experiments: Each of the five strains was pre-grown, harvested, washed, and finally re-suspended (to a final cell density of $1 \times 10^{9}$ cells $\mathrm{mL}^{-1}$ ) in $15 \mathrm{~mL}$ of HBS medium (in $15 \mathrm{~mL}$ Falcon tubes to allow little headspace for aeration; $\mathrm{pH} 2.0$ ) containing $10 \mathrm{mM} \mathrm{Fe}(\mathrm{III})$ (as $\mathrm{Fe}_{2}\left(\mathrm{SO}_{4}\right)_{3} \cdot \mathrm{nH}_{2} \mathrm{O}$ ). Reagents were not $\mathrm{N}_{2}$-purged. One millimolar glucose was used as electron donor (except that $0.01 \% \mathrm{~S}^{0}$ was used for autotrophic S. metallicus Kra23). The Falcon tubes were incubated unshaken at $70^{\circ} \mathrm{C}$. Samples were regularly taken (using syringe needles for anaerobic experiments) to monitor concentrations of $\mathrm{Fe}(\mathrm{II})$ and total soluble Fe. All of the experiments were conducted in duplicates. The specific Fe(III) reduction rates $\left(\mathrm{mg}-\mathrm{Fe} \mathrm{h}^{-1}\left(1 \times 10^{10} \text { cells }\right)^{-1}\right.$ for anaerobic experiments; $\mathrm{mg}-\mathrm{Fe} \mathrm{h}^{-1}\left(1.5 \times 10^{10} \text { cells }\right)^{-1}$ for micro-aerobic experiments) were calculated. 


\section{Growth-coupled dissimilatory Fe(III) reduction test under anaerobic conditions}

In order to investigate whether or not $\mathrm{Fe}(\mathrm{III})$ can serve as sole electron acceptor for Sulfolobus growth, correlation between cell density and Fe(III) reduction was monitored after inoculation under strictly anaerobic condition. Each of the five strains was pre-grown and inoculated (to a final cell density of $1 \times 10^{7}$ cells $\mathrm{mL}^{-1}$ ) into $20 \mathrm{~mL}$ of HBS medium (in $25 \mathrm{~mL}$ serum bottles with rubber stoppers; $\mathrm{pH}$ 2.0) containing either

Samples were taken using $\mathrm{N}_{2}$-purged syringe needles. The positive pressure inside the serum bottles automatically pushed out the liquid sample as the needle was stuck into the bottle, preventing contamination of oxygen. Cell densities (Thoma counting 
chamber, phase contrast microscope) and concentrations of $\mathrm{Fe}(\mathrm{II})$ and total soluble $\mathrm{Fe}$ were regularly monitored from duplicate flasks.

\section{$\mathrm{Cr}(\mathrm{VI})$ reduction test using growth-uncoupled cell-suspensions under micro-aerobic} conditions

Cell-suspensions $\left(1 \times 10^{9}\right.$ cells $\mathrm{mL}^{-1}$; in $50 \mathrm{~mL}$ HBS medium $(\mathrm{pH} 2.0)$ in $50 \mathrm{~mL}$ Falcon tubes) were prepared for each strain as described in previous sections. One millimolar glucose (or $0.01 \% \mathrm{~S}^{0}$ in the case of $S$. metallicus $\mathrm{Kra} 23$ ) and $0.2 \mathrm{mM} \mathrm{Cr}(\mathrm{VI})$ (as $\mathrm{Na}_{2} \mathrm{CrO}_{4} \cdot 4 \mathrm{H}_{2} \mathrm{O}$ ) were added to the cell-suspensions, which were then incubated at $70^{\circ} \mathrm{C}$ without shaking. Samples were regularly taken to monitor concentrations of $\mathrm{Cr}(\mathrm{VI})$ and total soluble Cr. All of the experiments were carried out in duplicates.

\section{Solution analysis}

Liquid samples were filtered using $0.20-\mu \mathrm{m}$ cartridge filters to determine concentrations of Fe(II) and total soluble Fe (o-phenanthroline method; Caldwell and Adams 1946, using ascorbic acid as a reducing agent), $\mathrm{Cr}(\mathrm{VI})$ (diphenylcarbazide method; Noroozifar and Khorasani-Motlagh 2003), and total soluble Cr (ICP-OES; SEIKO Vista-MPX). 


\section{Results and Discussion}

217 Comparison of Fe(II) oxidation by five Sulfolobus strains in growth-uncoupled cell-

\section{suspensions under aerobic condition}

Fe(II) oxidation in cell-suspensions of five Sulfolobus strains are compared in

Figure 1. No further cell growth was observed in cell-suspensions during the experiments

by cell counting (data not shown). A decrease in total Fe concentrations in cellsuspensions during $\mathrm{Fe}(\mathrm{II})$ oxidation experiments was attributed to $\mathrm{Fe}(\mathrm{III})$ precipitation (data not shown), rather than Fe sorption on cell surfaces. Thus, any decline in Fe(II) was attributed to oxidation of $\mathrm{Fe}(\mathrm{II})$ to $\mathrm{Fe}(\mathrm{III})$.

The Fe(II) oxidation rates $\left(\mathrm{mg}-\mathrm{Fe} \mathrm{h}^{-1}\right.$ for comparison between abiotic and biotic $\mathrm{Fe}(\mathrm{II})$ oxidations) and specific $\mathrm{Fe}(\mathrm{II})$ oxidation rates $\left(\mathrm{mg}-\mathrm{Fe} \mathrm{h}^{-1}\right.$ cell ${ }^{-1}$ for comparison between Sulfolobus strains) were calculated (using the data points from designated hours in Figure 1) and listed in Table 1. S. solfataricus P1 and S. shibatae B12 showed only negligible Fe(II) oxidation, compared with the abiotic counterpart. The most effective Fe(II) oxidation was observed in cell-suspensions of $S$. metallicus Kra23, followed by $S$. tokodaii 7 (Figure 1). It should be noted that the final cell density regularly achieved in pre-grown cultures (for preparation of cell-suspensions) of strictly autotrophic $S$. metallicus Kra23 (approx. $2 \times 10^{8}$ cells $\mathrm{mL}^{-1}$ ) was much lower than that of heterotrophic 
234 S. tokodaii 7 (approx. $5 \times 10^{8}$ cells $\mathrm{mL}^{-1}$ ). Therefore, the specific Fe(II) oxidation rate (mg-

$235 \mathrm{Fe} \mathrm{h}^{-1}$ cell $^{-1}$ ) was over 4 times greater with $S$. metallicus Kra23 than with S. tokodaii 7

236 (Table 1). S. acidocaldarius 98-3 was less effective Fe(II) oxidizer than S. metallicus

237 Kra23 and S. tokodaii 7, but marginally more effective than the rest (Figure 1; Table 1).

238 Theoretical conversion from per cell to per g-protein (Table 1) found that the specific

$239 \mathrm{Fe}(\mathrm{II})$ oxidation rate $\left(\mathrm{mg}-\mathrm{Fe} \mathrm{h}^{-1}\right.$ g-protein $\left.^{-1}\right)$ of $S$. metallicus $\mathrm{Kra} 23$ is still much smaller

240 than those of Fe(II) oxidizing bacteria (Johnson et al., 2012), although a simultaneous

241 comparison test would be needed to confirm this observation. Bathe and Norris (2007)

242 reported that $S$. tokodaii readily oxidized Fe(II) during heterotrophic growth on yeast

243 extract, but its autotrophic Fe(II) oxidation was much weaker than that by S. metallicus.

244 Our results demonstrated that S. metallicus Kra23 and S. tokodaii 7 oxidize Fe(II) much

245 more readily than the others tested. Since $S$. metallicus is the only known strictly

246 autotrophic type strain in the genus (Huber and Stetter 1991), it is reasonable that this

247 species oxidizes Fe(II) much more effectively than all the others to support its growth.

Putative genes possibly involved in Fe(II) oxidation / Fe(III) reduction in

Sulfolobus spp. were summarized in Supplemental Table 1. Based on the available 
non- or minor-Fe(II) oxidizing ( $S$. solfataricus or S. acidocaldarius, respectively) strains.

253 A clear difference was the presence of the fox gene cluster solely in Fe(II)-oxidizing

254 strains (S. metallicus and S. tokodaii), as was previously suggested by Bathe and Norris

255 (2007). Whether or not Sox, Cbs, Ods and/or proteins with some homology to Fe(II)-

256 upregulated genes of At. ferrooxidans (Quairini et al., 2009; Supplemental Table 1) are

257 possibly responsible for any minor Fe(II) oxidation (e.g., by $S$. acidocardarius) is yet

258 unclear.

259

260

261

262

263

\section{Comparison of $\mathrm{Fe}$ (III) reduction by five Sulfolobus strains in growth-uncoupled cell-}

\section{suspensions under anaerobic / micro-aerobic conditions}

Among the five Sulfolobus strains tested, only S. metallicus Kra23 is known to grow autotrophically on $\mathrm{S}^{0}$ as energy source (Huber and Stetter 1991). Other five strains grow heterotrophically on glucose as sole electron donor (Grogan 1989; Grogan et al. 1990; Suzuki et al. 2002; Masaki et al. 2016). The following Fe(III) reduction experiments therefore used $\mathrm{S}^{0}$ and glucose as electron donor for S. metallicus Kra23 and the rest, respectively.

$\mathrm{Fe}(\mathrm{III})$ reduction in cell-suspensions of five Sulfolobus strains under anaerobic and micro-aerobic conditions are compared in Figure 2 and 3, respectively. No further 
cell growth was seen in cell-suspensions during the experiments by cell counting (data not shown). The rates of Fe(III) reduction $\left(\mathrm{mg}^{-} \mathrm{Fe} \mathrm{h}^{-1}\right.$ ) and specific Fe(III) reduction (mg-

$272 \mathrm{Fe} \mathrm{h}^{-1}$ cell $^{-1}$ ) were calculated (using the data points from designated hours in Figure 2 and 3) and listed in Table 2.

S. metallicus Kra23, the strongest Fe(II) oxidizer among the five strains, was shown to be also the most effective Fe(III) reducer under anaerobic conditions (Figure 2a; Table 2). When tested micro-aerobically, however, its Fe(III)-reducing ability was almost totally suppressed (Figure 3a; Table 2).

S. tokodaii 7 readily reduced Fe(III) under anaerobic conditions with both $\mathrm{S}^{0}$ and glucose as electron donor (Figure 2b; Table 2). Under micro-aerobic conditions, however, $\mathrm{Fe}(\mathrm{III})$ reduction started off to build up Fe(II) for the first 20 hours, but later switching to an apparent $\mathrm{Fe}$ (II) oxidation phase (20-65 hours), which was finally followed solely by steady Fe(III) reduction (Figure 3b). The Fe(II) hump between 0-65 hours in glucose-free controls mimicked (but about half) that with glucose addition (Figure 3b). This is likely due to the presence of residual intracellular electron carriers, such as NADH, accumulated during pre-growth (Magnuson et al. 2000; Okibe et al., 2017). Therefore, this observation may be explained by a gradual and steady depletion of oxygen in the system as follows: During 0-20 hours, electrons (deriving from externally added glucose plus residual 
intracellular NADH) were supposedly accepted by both oxygen and some Fe(III). Buildup of a certain amount of the resultant $\mathrm{Fe}$ (II) may have triggered $\mathrm{Fe}(\mathrm{II})$ oxidation with the residual oxygen (20-65 hours). Eventually, the oxygen was consumed to support steady Fe(III) reduction (after 65 hours). readily with glucose than $\mathrm{S}^{0}$ as electron donor) under anaerobic conditions (Figure 2d;

S. solfataricus $\mathrm{P} 1$ also displayed fairly strong Fe(III)-reducing ability (more Table 2), which was slightly negatively affected by the presence of residual oxygen when glucose was used as electron donor (Figure 3d; Table 2).

S. acidocaldarius $98-3$ and $S$. shibatae B12 showed the least Fe(III) reduction among the five strains under anaerobic conditions (glucose was the better electron donor than $\mathrm{S}^{0}$ for $\mathrm{Fe}(\mathrm{III})$ reduction in both strains) (Figure 2c, e; Table 2). However, Fe(III) reduction by the two strains were greatly facilitated under micro-aerobic conditions, showing the most effective Fe(III) reduction among the five strains (Figure 3c, e; Table 2). Again, this was not caused by a cell number increase in the presence of residual oxygen, since there was no further cell growth in cell-suspensions during the experiment (by cell counting; data not shown). A similar observation was reported with $\mathrm{Fe}(\mathrm{III})$ reduction by Acidiphilium spp.: Whilst most strains do not grow under strictly anoxic conditions in the presence of $\mathrm{Fe}(\mathrm{III})$, growth-coupled $\mathrm{Fe}(\mathrm{III})$ reduction was most readily observed under 
306 micro-aerobic conditions (Johnson and McGinness, 1991; Bridge and Johnson,2000).

307 Fe(III) reduction was constitutive in A. cryptum SJH but was inducible in A. acidophilum 308 and low oxygen concentrations, rather than Fe(III) was suggested to induce a putative 309 "iron reductase" in the latter (Bridge and Johnson,2000; Johnson et al., 2012). This could 310 possibly be the case also for some Sulfolobus spp.. Relatively high standard redox 311 potential of $\mathrm{Fe}(\mathrm{III}) / \mathrm{Fe}(\mathrm{II})(+0.76 \mathrm{~V}$; $\mathrm{pH} 2.0)$, comparable to that of $1 / 2 \mathrm{O}_{2} / \mathrm{H}_{2} \mathrm{O}(+0.82 \mathrm{~V})$, 312 makes iron favorable alternative electron acceptor for acidophiles (Madigan and Martinko 313 2006). The results suggested that this is also applicable to Sulfolobus spp. under 314 both/either microaerobic and/or anaerobic condition. Theoretical conversion of the specific Fe(III) reduction rate from per cell to per

316 g-protein (Table 2) indicated that Fe(III) reduction by S. metallicus Kra23 (anaerobic 317 condition) is comparable to that reported in other bacterial counterparts (Johnson et al., 318 2012). However, again, a simultaneous comparison is necessary to verify this (Johnson et 319 al., 2012). anaerobic conditions 
were observed in S. tokodaii 7 (Figure 4b), S. solfataricus P1 (Figure 4d) and S. shibatae B12 (Figure 4e) (Figure 4f), indicating that cell growth of these three strains is supported by Fe(III) reduction using glucose as electron donor.

In the case of other two strains, S. metallicus Kra23 and S. acidocaldarius 98-3, Fe(III) reduction did occur by the existing cells, but no correlation between cell growth and Fe(III) reduction was found (Figure 4a, c). Interestingly, the microbial capability of growth-coupled Fe(III) respiration (Figure 4) did not necessarily correspond to efficient Fe(III) reduction in its growth-uncoupled cell suspensions (Figures 2, 3). The results from a series of Fe(III) reduction experiments using cell-suspensions (Figure 2, 3) revealed that all tested Sulfolobus spp. showed major Fe(III) reduction compared to sterile controls, either/both under anaerobic (Figure 2) or/and micro-aerobic (Figure 3) conditions, as summarized as follows:

(i) S. metallicus Kra23 (Figures 2-4a): Strong Fe(III) reducer under anaerobic conditions, though incapable of anaerobic growth using $\mathrm{S}^{0}$ and $\mathrm{Fe}(\mathrm{III})$ as sole electron donor and acceptor, respectively; residual oxygen significantly suppresses its Fe(III) reduction. (ii) S. tokodaii 7 (Figures 2-4b): Readily reduces Fe(III) under anaerobic conditions; its $\mathrm{Fe}(\mathrm{II})$ oxidation can overtake Fe(III) reduction in the presence of residual oxygen, exhibiting apparent alternate switch on/off of $\mathrm{Fe}(\mathrm{III})$ reduction and $\mathrm{Fe}(\mathrm{II})$ 
342 oxidation; anaerobic cell growth coupled with Fe(III) reduction using glucose as sole 343 electron donor. (iii) S. solfataricus P1 (Figures 2-4d): Readily reduces Fe(III) under both 344 anaerobic and micro-aerobic conditions; anaerobic cell growth likely coupled with Fe(III) 345 reduction using glucose and Fe(III) as sole electron donor and acceptor, respectively. (iv) 346 S. acidocaldarius 98-3 (Figures 2-4c): No clear evidence for anaerobic Fe(III) reduction, 347 whilst micro-aerobic conditions significantly facilitate its Fe(III)-reducing ability; no 348 anaerobic growth observed using glucose and Fe(III) as sole electron donor and acceptor, 349 respectively. (v) (Figures 2-4e) S. shibatae B12: Anaerobic Fe(III) reduction is negligible, 350 whilst micro-aerobic conditions significantly accelerate its Fe(III)-reducing ability; 352 donor). reduction mechanisms seem to take place differently from that of $F$. placidus 355 (Supplemental Table 1; Smith et al., 2015). However, genomic sequence analysis detected 356 Ferp_1268 (4Fe-4S ferredoxin iron-sulfur binding domain protein) and Ferp_1269 (NrfD; polysulphide reductase)-like proteins in S. tokodaii, S. acidocaldarius and S. solfataricus (Supplemental Table 1). By utilizing different cytochrome systems (e.g., cytochrome b558/566, as was suggested in Fe(II) oxidation mechanism) it may still be possible that $4 \mathrm{Fe}-$ 
4S ferredoxin and/or polysulphide reductase-type protein are involved in the Fe(III) reduction mechanism of Sulfolobus spp.. Nonetheless, such hypothesis requires detailed biochemical studies to be clarified.

Comparison of $\mathrm{Cr}(\mathrm{VI})$ reduction by five Sulfolobus strains in growth-uncoupled cellsuspensions under micro-aerobic condition

Following the previous observation that Fe(III)-reducing Sulfolobus sp. GA1 is also capable of $\mathrm{Cr}(\mathrm{VI})$ reduction to $\mathrm{Cr}$ (III) (Masaki et al. 2016), this study tested five Sulfolobus strains to investigate whether or not $\mathrm{Cr}(\mathrm{VI})$-reducing ability is also widely found across different representative Sulfolobus species.

No further cell growth was observed in cell-suspensions during the experiments (by cell counting; data not shown). Since no changes in total soluble $\mathrm{Cr}$ concentration were observed throughout the experiment (data not shown), $\mathrm{Cr}(\mathrm{VI})$ reduced by Sulfolobus strains remained soluble mostly in the form of $\mathrm{Cr}(\mathrm{III})$. Liquid media were free of any trace of iron and no noticeable abiotic reduction of $\mathrm{Cr}(\mathrm{VI})$ was observed in sterile controls (Figure 5).

All five strains were found to reduce $\mathrm{Cr}(\mathrm{VI})$, though to a different extent (Figure 5) and with different specific $\mathrm{Cr}(\mathrm{VI})$ reduction rates (Table 3). Interestingly, the trend in 
degree of $\mathrm{Fe}(\mathrm{III})$ reduction by five strains (under the same micro-aerobic conditions) did not necessarily correspond to that of $\mathrm{Cr}(\mathrm{VI})$ reduction: e.g., S. acidocaldarius $98-3$ and $S$. shibatae $\mathrm{B} 12$ showed the highest $\mathrm{Fe}(\mathrm{III})$ reduction under micro-aerobic conditions (Figure 3c, e, respectively). Nonetheless, the former was the least effective $\mathrm{Cr}(\mathrm{VI})$ reducer while the latter was the most effective among the five strains.

Oxido-reduction of metal species is often mediated by cytochromes in electron transport chains: In the case of acidophilic bacteria, cytochromes $c$ in cell membranes were found to be involved in anaerobic Fe(III) reduction by At. ferrooxidans (Ohmura et al. 2002). $\mathrm{Cr}(\mathrm{VI})$ reduction by $\mathrm{Fe}(\mathrm{III})$-respiring acidophile A. cryptum was also reported to involve cytochromes $c$ (Magnuson et al. 2010). In the case of Fe(III)-reducing neutrophiles, cytochromes $c$ were found to function in Fe(III) reduction by Geobacter sulfurreducens (Magnuson et al. 2000) and both $\mathrm{Fe}(\mathrm{III})$ and $\mathrm{Cr}(\mathrm{VI})$ reduction by Shewanella putrefaciens (Beliaev et al. 2001). In the latter bacterium, $\mathrm{Cr}(\mathrm{VI})$ reductase was reported to be distinct from Fe(III) reductase, and was not irreversibly inhibited by oxygen (Myers et al. 2000). The fact that the trend in Fe(III) reduction by five Sulfolobus strains does not always match that in $\mathrm{Cr}(\mathrm{VI})$ reduction implies that different mechanisms may be involved in microbial reduction of the two metals in Sulfolobus spp., as was the case with Shewanella putrefaciens (Beliaev et al. 2001). 


\section{Conclusions}

398 This study clarified the presence and the degree of Fe oxido-reduction abilities in five representative Sulfolobus strains (S. metallicus Kra23; S. tokodaii 7; S. acidocaldarius 98-3; S. solfataricus P1; S. shibatae B12). The degree of Fe(II)-oxidizing abilities were found to differ largely between the strains. Three strains (S. tokodaii 7, S. solfataricus P1 and $S$. shibatae B12) were capable of growth via Fe(III) respiration. All five strains displayed Fe(III)-reducing abilities in growth-uncoupled cell-suspensions: Nonetheless, Fe(III)-reducing ability in each strain responded significantly differently to the oxygen level. Highly-toxic Cr(VI) was also reduced in growth-uncoupled cell-suspensions of all strains, though to a varying degree. The trend of Fe(III) reduction in five strains did not correspond to that of $\mathrm{Cr}(\mathrm{VI})$, suggesting different mechanisms being involved in $\mathrm{Fe}(\mathrm{III})$ and $\mathrm{Cr}(\mathrm{VI})$ reduction in Sulfolobus spp. For being a major member in the acidophile community, Fe redox transformation in the genus Sulfolobus remained so far largely ambiguous. The results of this study provide comprehensive understandings over the genus Sulfolobus on its Fe redox transformation capabilities and the potential utility of the Sulfolobus spp. for biohydrometallugical applications. 


\section{Acknowledgments}

415 Y.M. is thankful to financial support provided by the Kyushu University Advanced 416 Graduate Program in Global Strategy for Green Asia.

\section{$418 \quad$ References}

419 Auernik KS, Maezato Y, Blum PH, Kelly RM. 2008. The genome sequence of the metal420 mobilizing, extremely thermoacidophilic archaeon Metallosphaera sedula provides 421 insights into bioleaching-associated metabolism. Appl Environ Microbiol 74: 682-692.

Bathe S, Norris PR. 2007. Ferrous iron- and sulfur-induced genes in Sulfolobus metallicus.

Appl Environ Microbiol 73:2491-2497.

Beliaev AS, Saffarini DA, McLaughlin JL, Hunnicutt D. 2001. MtrC, an outer membrane decahaem $c$ cytochrome required for metal reduction in Shewanella putrefaciens MR-1. Mol Microbiol 39:722-730. Bonnefoy V, Holmes DS. 2012. Genomic insights into microbial iron oxidation and iron uptake strategies in extremely acidic environments. Environ Microbiol 14:1597-1611. 
Bridge TAM, Johnson DB. 1998. Reduction of soluble iron and reductive dissolution of

434 ferric iron-containing minerals by moderately thermophilic iron-oxidizing bacteria. Appl

435 Environ Microbiol 64:2181-2186.

436

437 Brock TD, Brock KM, Belly RT, Weiss RL. 1972. Sulfolobus: A new genus of sulfur438 oxidizing bacteria living at low $\mathrm{pH}$ and high temperature. Arch Microbiol 84:54-68.

440 Brock TD, Cook S, Petersen S, Mosser JL. 1976. Biogeochemistry and bacteriology of 441 ferrous iron oxidation in geothermal habitats. Geochim Cosmochim Ac 40:493-500.

Brock TD, Gustafson J. 1976. Ferric iron reduction by sulfur- and iron-oxidizing bacteria. Appl Environ Microbiol 32:567-571.

446 Caldwell DH, Adams RB. 1946. Colorimetric determination of iron in water with $o$ phenanthroline. J Am Water Works Ass 38:727-730. 
449 Chen L, Brügger K, Skovgaard M, Redder P, She Q, Torarinsson E, Greve B, Awayez M, 450 Zibat A, Klenk HP, Garrett RA. 2005. The genome of Sulfolobus acidocaldarius, a model 451 organism of the Crenarchaeota. J Bacteriol 187:4992-4999.

Coupland K, Johnson DB. 2008. Evidence that the potential for dissimilatory ferric iron reduction is widespread among acidophilic heterotrophic bacteria. FEMS Microbiol Lett 279:30-35. Reduction of $\mathrm{Cr}(\mathrm{VI})$ under acidic conditions by the facultative Fe(III)-reducing bacterium Acidiphilium cryptum. Environ Sci Technol 41:146-152.

Dean JA. 1999. Lange's Handbook of Chemistry 15th edn, New York:McGraw-Hill.

Gautier V, Escobar B, Vargas T. 2008. Cooperative action of attached and planktonic cells during bioleaching of chalcopyrite with Sulfolobus metallicus at $70^{\circ} \mathrm{C}$. Hydrometallurgy 94:121-126. 
466 Fredrickson LK, Romine MF, Beliaev AS, Auchtung JM, Driscoll ME, Gardner TS, 467 Nealson KH, Osterman AL, Pinchuk G, Reed JL, Rodionov DA, Rodrigues JLM, 468 Saffarini DA, Serres MH, Spormann AM, Zhulin IB, Tiedje JM. 2008. Towards 469 environmental systems biology of Shewanella. Nature Rev Microbiol 6:592-603.

Grogan D, Palm P, Zillig W. 1990. Isolate B12, which harbours a virus-like element, represents a new species of the archaebacterial genus Sulfolobus, Sulfolobus shibatae, sp. nov. Arch Microbiol 154:594-599.

Grogan DW. 1989. Phenotypic characterization of the archaebacterial genus Sulfolobus: comparison of five wild-type strains. J Bacteriol 171:6710-6719. Hallberg KB, Grail BM, du Plessis CA, Johnson DB. 2011a. Reductive dissolution of ferric iron minerals: A new approach for bio-processing nickel laterites. Miner Eng 24:620-624. 
Hallberg KB, Hedrich S, Johnson DB. 2011b. Acidiferrobacter thiooxydans, gen. nov. sp. nov.; an acidophilic, thermo-tolerant, facultatively anaerobic iron- and sulfur-oxidizer of the family Ectothiorhodospiraceae. Extremophiles 15:271-279.

Hallberg KB, Toril EG, Johnson DB. 2010. Acidithiobacillus ferrivorans, sp. nov.; facultatively anaerobic, psychrotolerant iron-, and sulfur-oxidizing acidophiles isolated from metal mine-impacted environments. Extremophiles 14:9-19.

Hiller A, Henninger T, Schäfer G, Schmidt CL. 2003. New genes encoding subunits of a cytochrome $b c$-analogous complex in the respiratory chain of the hyperthermoacidophilic crenarchaeon Sulfolobus acidocaldarius. J Bioenerg Biomembr $35: 121-131$.

Huber G, Stetter KO. 1991. Sulfolobus metallicus, sp. nov., a novel strictly chemolithoautotrophic thermophilic archaeal species of metal-mobilizers. Syst Appl Microbiol 14:372-378.

Jan RL, Wu J, Chaw SM, Tsai CW, Tsen SD. 1999. A novel species of thermoacidophilic archaeon, Sulfolobus yangmingensis sp. nov. Int J Syst Bacteriol 49:1809-1816. 
501 Johnson DB, Bridge TAM. 2002. Reduction of ferric iron by acidophilic heterotrophic 502 bacteria: evidence for constitutive and inducible enzyme systems in Acidiphilium spp. J Appl Microbiol 92:315-321.

504

505 Johnson DB, Grail BM, Hallberg KB. 2013. A new direction for biomining: Extraction 506 of metals by reductive dissolution of oxidized ores. Minerals 3:49-58.

Johnson DB, Kanao T, Hedrich S. 2012. Redox transformations of iron at extremely low pH: fundamental and applied aspects. Front Microbiol 3:1-13.

511 Johnson DB, McGinness S. 1991. Ferric iron reduction by acidophilic heterotrophic 512 bacteria. Appl Environ Microbiol 57:207-211.

514 Johnson DB, Stallwood B, Kimura S, Hallberg KB. 2006. Isolation and characterization 515 of Acidicaldus organivorus, gen. nov., sp. nov.: a novel sulfur-oxidizing, ferric iron516 reducing thermo-acidophilic heterotrophic Proteobacterium. Arch Microbiol 185:212221. 
519 Johnson DB. 2012. Reductive dissolution of minerals and selective recovery of metals

520 using acidophilic iron- and sulfate-reducing acidophiles. Hydrometallurgy 127-128:172-

$521 \quad 177$

522

523 Kawarabayasi Y, Hino Y, Horikawa H, Jin-no K, Takahashi M, Sekine M, Baba

524 S, Ankai A, Kosugi H, Hosoyama A, Fukui S, Nagai Y, Nishijima K, Otsuka

525 R, Nakazawa H, Takamiya M, Kato Y, Yoshizawa T, Tanaka T, Kudoh Y, Yamazaki

526 J, Kushida N, Oguchi A, Aoki K, Masuda S, Yanagii M, Nishimura M, Yamagishi

527 A, Oshima T, Kikuchi H. 2001. Complete genome sequence of an aerobic 528 thermoacidophilic crenarchaeon, Sulfolobus tokodaii strain7. DNA Res 8:123-140.

530 Loferer-Krößbacher M, Klima J, Psenner R. 1998. Determination of bacterial cell dry mass by transmission electron microscopy and densitometric image analysis. Appl

Environ Microbiol 64:688-694. 
C, Nevin KP. 2011. Geobacter: The microbe electric's physiology, ecology, and practical applications. Adv Microb Physiol 59:1-100.

Madigan MT, Martinko JM. 2006. Brock Biology of Microorganisms 11th edn, New Jersey:Pearson.

Madigan MT, Martinko JM, Clark DP, Stahl DA. 201. Brock Biology of Microorganisms

13th edn, Benjamin-Cummings Publishing Company.

Magnuson TS, Hodges-Myerson AL, Lovley DR. 2000. Characterization of a membrane-

bound $\mathrm{NADH}$-dependent $\mathrm{Fe}^{3+}$ reductase from the dissimilatory $\mathrm{Fe}^{3+}$-reducing bacterium

Geobacter sulfurreducens. FEMS Microbiol Lett 185:205-211.

Magnuson TS, Swenson MW, Paszczynski AJ, Deobald LA, Kerk D, Cummings DE. 2010. Proteogenomic and functional analysis of chromate reduction in Acidiphilium cryptum JF-5, an Fe(III)-respiring acidophile. Biometals 23:1129-1138. 
Masaki Y, Hirajima T, Sasaki K, Okibe, N. 2015. Bioreduction and immobilization of hexavalent chromium by the extremely acidophilic Fe(III)-reducing bacterium Acidocella aromatica strain PFBC. Extremophiles 19:495-503.

Masaki Y, Tsutsumi K, Hirano S, Okibe N. 2016. Microbial community profiling of

Chinoike Jigoku ("Blood Pond Hell”) hot spring in Beppu, Japan and isolation and characterization of Fe(III)-reducing Sulfolobus sp. strain GA1. Res Microbiol 167:595603. activity is associated with the cytoplasmic membrane of anaerobically grown Shewanella putrefaciens MR-1. J Appl Microbiol 88:98-106.

566 Ñancucheo I, Grail BM, Hilario F, du Plessis C, Johnson DB. 2014. Extraction of copper from an oxidized (lateritic) ore using bacterially catalysed reductive dissolution. Appl Microbiol Biotechnol 98:6297-6305. 
570 Neidhardt FC, Ingraham JL, Schaechter M. 1990. Physiology of the bacterial cell: a 571 molecular approach. Sinauer Associates, Sunderland, Mass.

573 Noroozifar M, Khorasani-Motlagh M. 2003. Specific extraction of chromium as 574 tetrabutylammonium-chromate and spectrophotometric determination by 575 diphenylcarbazide: speciation of chromium in effluent streams. Anal Sci 19:705-708.

577 Ohmura N, Sasaki K, Matsumoto N, Saiki H. 2002. Anaerobic respiration using $\mathrm{Fe}^{3+}, \mathrm{S}^{0}$, 578 and $\mathrm{H}_{2}$ in the chemolithoautotrophic bacterium Acidithiobacillus ferrooxidans. J 579 Bacteriol 184:2081-2087.

581 Osorio H, Mangold S, Denis Y, Ñancucheo I, Esparza M, Johnson DB, Bonnefoy V, 582 Dopson M, Holmes DS. 2013. Anaerobic sulfur metabolism coupled to dissimilatory iron reduction in the extremophile Acidithiobacillus ferrooxidans. Appl Environ Microbiol 79:2172-2181. 
Quatrini R, Appia-Ayme C, Denis Y, Jedlicki E, Holmes DS, Bonnefoy V. 2009.

Extending the models for iron and sulfur oxidation in the extreme acidophile Acidithiobacillus ferrooxidans. BMC Genomics 10:394.

Sandström Å, Shchukarev A, Paul J. 2005. XPS characterisation of chalcopyrite

She Q, Singh RK, Confalonieri F, Zivanovic Y, Allard G, Awayez MJ, Chan-Weiher CC,

Clausen IG, Curtis BA, De Moors A, Erauso G, Fletcher C, Gordon PM, Heikamp-de

Jong I, Jeffries AC, Kozera CJ, Medina N, Peng X, Thi-Ngoc HP, Redder P, Schenk ME,

RA, Ragan MA, Sensen CW, Van der Oost J. 2001. The complete genome of the crenarchaeon Sulfolobus solfataricus P2. Proc Natl Acad Sci USA 98:7835-7840.

Smith JA, Aklujkar M, Risso C, Leang C, Giloteaux L, Holmes DE. 2015. Mechanisms involved in $\mathrm{Fe}(\mathrm{III})$ respiration by the hyperthermophilic archaeon Ferroglobus placidus. 

genus Sulfolobus isolated from Beppu Hot Springs, Japan. Extremophiles 6:39-44.

606

Urbieta MS, Rascovan N, Vázquez MP, Donati E. 2017. Genome analysis of the thermoacidophilic archaeon Acidianus copahuensis focusing on the metabolisms associated to biomining activities. BMC Genomics 18: 445.

610

C. 2008. Bioleaching of chalcopyrite with thermophiles:

614 Xiang X, Dong X, Huang L. 2003. Sulfolobus tengchongensis sp. nov., a novel 615 thermoacidophilic archaeon isolated from a hot spring in Tengchong, China. 616 Extremophiles 7:493-498. 2011. Sulfur oxidation activities of pure and mixed thermophiles and sulfur speciation in bioleaching of chalcopyrite. Bioresour Technol 102:3877-3882. 
622 Zillig W, Kletzin A, Schleper C, Holz I, Janekovic D, Hain J, Lanzendörfer M, 623 Kristjansson JK. 1993. Screening for Sulfolobales, their plasmids and their viruses in 624 Icelandic solfataras. Syst Appl Microbiol 16:609-628.

625 


\section{Figure 1.}

Growth-uncoupled Fe(II) oxidation in cell-suspensions of five Sulfolobus strains (pH 2.0, tokodaii 7; S. shibatae B12).

635

Figure 2.

637

Growth-uncoupled Fe(III) reduction in cell-suspensions of five Sulfolobus strains (pH 2.0, $70^{\circ} \mathrm{C}$, anaerobic conditions):

(a) S. metallicus Kra23,

(b) S. tokodaii 7, (c) $S$. acidocaldarius 98-3, (d) S. solfataricus P1, (e) S. shibatae B12, (f) sterile controls. lines indicate concentrations of total soluble Fe or Fe(II), respectively. Duplicate data are individually plotted. 


\section{Figure 3.}

645 Growth-uncoupled Fe(III) reduction in cell-suspensions of five Sulfolobus strains (pH 2.0, $64670^{\circ} \mathrm{C}$, micro-aerobic conditions): (a) S. metallicus Kra23 (0-25 h), (b) S. tokodaii 7 (0-25 647 h), (c) S. acidocaldarius 98-3 (0-100 h), (d) S. solfataricus P1 (0-25 h), (e) S. shibatae B12 (0-100 h), (f) sterile controls $(0-100$ h). Glucose $(\mathbf{O}, \bigcirc)$ or elemental sulfur

650 Solid or broken lines indicate concentrations of total soluble Fe or Fe(II), respectively.

651

652

653

654

655

656

657

Duplicate data are individually plotted.

\section{Figure 4.}

Correlation between anaerobic cell growth and the amount of $\mathrm{Fe}(\mathrm{III})$ reduced by five Sulfolobus strains (pH 2.0, $70^{\circ} \mathrm{C}$ ): (a) S. metallicus Kra23, (b) S. tokodaii 7, (c) S. acidocaldarius 98-3, (d) S. solfataricus P1, (e) S. shibatae B12. The initial Fe(III) concentration used were $0(\boldsymbol{\nabla}), 5(\mathbf{O}), 10(\mathbf{\square})$, or $15(\boldsymbol{\Delta}) \mathrm{mM}$. The number indicated for each plot indicates the time for sampling. Data points are the average of two measurements from duplicate flasks (error bars show the average difference in the two values). 
$\mathrm{Cr}(\mathrm{VI})$ reduction in cell-suspensions of five Sulfolobus strains $\left(\mathrm{pH} 2.0,70^{\circ} \mathrm{C}\right.$, microglucose $(+, \times)$ or elemental sulfur $(/, \backslash)$ as electron donor. Duplicate data are individually plotted.

Table 1.

$670 \mathrm{Fe}$ (II) oxidation rates and specific Fe(II) oxidation rates determined for five Sulfolobus strains in growth-uncoupled cell suspensions.

Table 2.

Fe(III) reduction rates and specific Fe(III) reduction rates determined for five Sulfolobus strains in growth-uncoupled cells suspensions under anaerobic or micro-aerobic conditions.

Table 3.

$\mathrm{Cr}(\mathrm{VI})$ reduction rates and specific $\mathrm{Cr}(\mathrm{VI})$ reduction rates determined for five Sulfolobus 

strains in growth-uncoupled cell suspensions under micro-aerobic condition.

681

682 Supplemental Table 1.

683 Putative genes possibly involved in Fe(II) oxidation / Fe(III) reduction in Sulfolobus spp.

684 searched using the KEGG (Kyoto Encyclopedia of Genes and Genomes) database. 